\title{
FAKTOR DAN STRATEGI PENCEGAHAN PEMARJINALAN BAHASA SUWAWA DI PROVINSI GORONTALO
}

\author{
Fatmah AR. Umar \\ FKIP Unversitas Negeri Gorontalo \\ e-mail: faruung@gmail.com
}

\begin{abstract}
Abstrak
Bahasa Suwawa merupakan bahasa daerah yang tertua "tiyombu" yang digunakan oleh masyarakat etnis Suwawa di wilayah Suwawa dan Bone Pantai Provinsi Gorontalo sejak zaman Purba (sekitar 300 SM). Bahasa Suwawa baik secara historis maupun yuridis memiliki kedudukan dan fungsi yang sangat penting. Akan tetapi, bahasa ini sudah mulai dimarjinalkan atau termarjinalkan. Tulisan ini bertujuan medeskripsikan faktor dan strategi pencegahan pemarjinalan bahasa Suwawa di Provinsi Gorontalo.Pendekatan yang digunakan adalah kualitatif-deskriptif. Teknik pengumpulan data meliputi pengamatan berperan serta, wawancara mendalam, dan studi dokumentasi. Hasil penelitian sebagai berikut. Pertama, pemarjinalan bahasa Suwawa disebabkan oleh (1) faktor konseptual, (2) faktor operasional, (3) faktor sikap, dan (4) faktor sikap bahasa. Kedua, strategi pencegahan pemarjinalan bahasa Suwawa dapat dilakukan melalui (1) jalur pendidikan, (2) jalur penelitian dan kegiatan ilmiah, dan (3) jalur pengabdian kepada masyarakat.
\end{abstract}

Kata kunci: faktor, strategi, pencegahan, pemarjinalan, bahasa Suwawa

\section{FACTORS AND STRATEGIES TO PREVENT THE MARGINALIZATION OF THE SUWAWA LANGUAGE IN GORONTALO PROVINCE}

\begin{abstract}
The Suwawa language is the oldest local language or "tiyombu" used by the Suwawa ethnic community in the areas of Suwawa and Bone Pantai in Gorontalo Province since the ancient time (around $300 \mathrm{BC}$ ). The Suwawa language, both historically and juridically, has a very important position and function. However, this language has begun to be marginalized. This study aims to describe factors and strategies to prevent the marginalization of the Suwawa language in Gorontalo Province. The study used the qualitative descriptive approach. The data were collected through participant observations, in-depth interviews, and documentation. The results of the study are as follows. First, the marginalization of the Suwawa language of Suwawa is caused by: (1) conceptual, (2) operational, (3) attitudinal, and (4) language-attitudinal factors. Second, strategies to prevent the marginalization of the Suwawa languagecan be applied through: (1) education, (2) research and scientific activities, and (3) community service.
\end{abstract}

Keywords: factors, strategies, prevention, marginalization, Suwawa language

\section{PENDAHULUAN}

Dilihat dari aspek sejarah (historis), bahasa Suwawa merupakan bahasa daerah tertua daripada bahasa Gorontalo, bahasa Atinggola, dan bahasa Bulango yang ada di Provinsi Gorontalo. Keberadaan bahasa Suwawa bersamaan dengan keberadaan Kerajaan Suwawa sejak zaman Purba sekitar 300 SM (Wantogia dan Wantogia, 1980:6-7). Itulah sebabnya bahasa 
Suwawa dan Kerjaan Suwawa disebut Tiyombu(leluhur). Sehubungan dengan hal ini, Kaluku (dalam Daulima, 2006:9), mengemukakan:

Masyarakat Gorontalo tumbuh bersamaan dengan terjadinya daratan Gorontalo. Semasih menjadi lautan masyarakat itu terdapat di Bangio atau Pinogu atau Tuwawa dalam ketinggian 1902 M. Masyarakat ini mempunyai raja secara turun temuruan sampai dengan raja XVIII. Setelah timbul daratan, maka ... masyarakat ini menyebar ke sepanjang pesisir Teluk Tomini. Ke sebelah Timur sampai ke Bolaang Mongondow, ke Selatan sampai ke Molibagu, Bolaang Uki, dan sekitarnya, ke sebelah Barat sampai ke Atinggola dan sekitarnya termasuk Buol Toli-toli. Hal ini dibuktikan dengan bahasa yang hampir sama dengan bahasa aslinya, yaitu bahasa Tuwawa (Suwawa). Masyarakat yang menyebar ini membentuk daerah kerajaan tersendiri sesuai dengan nama daerahnya masing-masing. Namun, kesemuanya tetap berpegang pada satu falsafat hidup, yaitu $U$ tuwawau - Duluwo - Limo Lo Pohala,... Dengan demikian, asal mula tempat nenek moyang kita adalah Tuwawa memiliki bukti yang kuat. Tuwawa berasal dari kata "Totowa", yang artinya satu badan yang terbujur dari Pinolosian mengarah ke wilayah Barat sampai ke gunung Boliohuto dan ke sebelah Selatan sampai ke Boalemo dan sekitarnya. Itulah daerah/wilayah dari kerajaan Tuwawa sampai saat itu.

Pendapat Kaluku, tampaknya identik dengan pendapat Daulima (2006:14), yaitu "Masyarakat Gorontalo baik yang tinggal di Kota Gorontalo maupun di Kabupaten Gorontalo berasal dari satu keturunan yaitu dari Tuwawa atau Bangio atau Pinogu". Oleh karena itu, perlu dijalin dan dibina rasa persatuan dan kesatuan antarsesama sebagaimana dilukiskan dalam ikrar berikut:

Wallahi adeya tutu 'demi Allah Yang Maha benar'

Tuwawa wagu Limbutu

'Suwawa dan Limboto'

Bi Tomita tutu

'hanya satu jua'

Woluo o buku

'ada dalam buku (sejarah)'

Mowali pusaka dotu

'menjadi pusaka turun temurun'

Dagai dao mogotu

'jaga jangan sampai putus'

Pomuluda no mohopu

'mengakibatkan kemusnahan'

Ditinjau dari segi yuridis, bahasa (Suwawa) memiliki kedudukan dan fungsi yang sangat kuat. Dasar yuridis yang dimaksud dipaparkan berikut. Pertama, UUD 1945 dan Amandemennya pasal 32 ayat 2 (perubahan keempat), dijelaskan "Negara menghormati dan memelihara bahasa daerah sebagai kekayaan budaya nasional". Kedua, Keputusan Kongres Bahasa Indonesia VII tahun 1998 (Badan Pengembangan dan Pembinaan Bahasa Kemendikbud, 2011a:86-87), dijelaskan "Pembinaan dan pengembangan bahasa daerah sebagai bagian kebudayaan Indonesia yang hidup perlu dilaksanakan secara lebih terencana".

Ketiga, UU Sisdiknas No. 20 Tahun 2003 Bab VII Pasal 33 ayat 2:17, dijelaskan "Bahasa daerah dapat digunakan sebagai bahasa pengantar dalam tahap awal pendidikan apabila diperlukan dalam penyampaian pengetahuan/dan atau keterampilan tertentu. Keempat, UU RI No. 24 Tahun 2009 tentang "Bendera, Bahasa, dan Lambang Negara, serta Lagu Kebangsaan" Bab III bagian ketiga pasal 42 ayat 1 dijelaskan Pemerintah Daerah wajib mengembangkan, membina, dan melindungi bahasa dan sastra daerah agar tetap memenuhi kedudukan dan fungsinya dalam kehidupan bermasyaratakt sesuai 
dengan perkembangan zaman dan agar tetap menjadi bagian dari kepercayaan budaya Indonesia", sedangkan ayat 2 dijelaskan "Pengembangan, pebinaan, dan perlindungan sebagaimana dimaksud pada ayat (1) dilakukan secara bertahap, sistematis, dan berkelanjutan oleh pemerintah daerah di bawah koordinasi lembaga kebahasaan".

Berdasarkan paparan tersebut di atas, jelaslah bahwa bahasa Suwawa sangat penting untuk dilestarikan dan dipertahankan keberadaannya sehingga tidak dimarjinalkan atau termarjinalkan. Prasaja (dalam Wahyudi, Ed. 2004:15), mengemukakan "Marginal adalah sesuatu yang kecil jumlahnya dan dianggap tidak penting serta tidak dilibatkan dalam perkembangan dan peristiwa utama". Wiryamartana (2004:66), mengatakan "Marginal dapat dipikirkan sebagai wilayah batas atau wilayah pinggir" menurut (1) tempat, (2) status sosial, (3) kekuasaan, (4) kekayaan, (5) kelompok etnis, dan (6) keterpelajaran. Lebih lanjut dikatakan, "Yang marginal berarti (1) yang ada di pinggiran, (2) rendah status sosialnya, (3) tak berkuasa, (4) miskin, (5) minoritas, dan (6) tak terpelajar. Dalam masyarakat ada kecenderungan yang marginal itu "termarginalkan atau dimarginalkan menjadi yang terabaikan, dipandang rendah, tertindas, tak diperhatikan, dan sebagainya.

Berdasarkan pengertian tentang margin dan marginal, maka kata pemarjinalan bahasa (Suwawa) dapat diartikan sebagai upaya langsung atau sengaja dilakukan oleh seseorang atau sekelompok orang untuk meminggirkan, menepikan, dan menggeser bentuk, kedudukan, dan fungsi bahasa Suwawa untuk digantikan dengan bahasa lain. Akibatnya masyarakat Suwawa tanpa disadari sudah dihinggapi sifat dan sikap waternisasi (kebarat-baratan).

Penelitian tentang pemarjinalan bahasa daerah sudah banyak dilakukan oleh para pakar. Namun penelitian mereka le- bih banyak menggunakan istilah “Pemertahanan" dan atau "Pergeseran". Pertama, hasil penelitian Sumarsono (dalam Chaer dan Agustina, 2004:147) menunjukkan (1) Penduduk desa Loloan yang berjumlah sekitar tiga ribu orang tidak menggunakan bahasa Bali, melainkan bahasa sejenis bahasa Melayu yang disebut bahasa Melayu Loloan sebagai B1-nya, ... , (2) di tengah-tengah B2 yang dominan, yaitu bahasa Bali, mereka dapat bertahan untuk tetap menggunakan B1-nya, yaitu bahasa Loloan sejak abad ke-18 lalu ketika leluhur mereka yang mengaku berasal dari Bugis dan Pontianak, (3) faktor mereka dapat bertahan dengan bahasa B1-nya, antara lain (i) wilayah pemukinaman mereka terkonsentrasi pada satu tempat yang secara geografis agak terpisah dari wilayah pemukiman masyarakat Bali, (ii) adanya toleransi dari masyarakat mayoritas Bali yang mau menggunakan bahasa Melayu Loloan dalam berinteraksi dengan golongan minorotas Loloan, meskipun dalam interaksi itu kadang-kadang digunakan bahasa Bali, (iii) adanya loyalitas yang tinggi dari anggota masyarakat Loloan terhadap bahasa Melayu Loloan sebagai konsekuensi kedudukan atau status bahasa ini menjadi lambang identitas dari masyarakat Bali yang beragama Hindu, dan (v) adanya kesinambungan pengalihan bahasa melayu Lolan dari generasi terdahulu ke generasi berikutnya.

Kedua, hasil penelitian Unesco yang dikutip Lauder (dalam Mbete, 2011:133) terhadap pewarisan bahasa daerah kepada generasi muda memilukan. Dari 90 bahasa minoritas yang disurvei di sejumlah Negara, hanya 36\% terwaris secara mulus, $64 \%$ tidak terwaris secara baik, $32 \%$ berfungsi, $68 \%$ bahasa minoritas itu tidak berfungsi lagi. Ketiga, hasil penelitian Bagus, dkk, Gunarwan, dan Mbete (dalam Gunarwan, 2011:137) menunjukkan ranah keluarga sebagai benteng terakhir, khususnya di kota dan di desadesa yang sudah tergolong maju, bahasa 
daerah tidak mendapat posisi dan fungsi penting lagi karena sudah diambil alih oleh bahasa Indonesia. Di samping itu, banyak ahli waris muda usia yang sudah malu, tidak percaya, dan tidak mampu menggunakan bahasa daerah. Makin kecil dan bahkan makin langkah pula ahli-ahli budaya dan bahasa daerah yang mencintai dan mengembangkan bahasa, sastra, dan budaya daerahnya. Keempat, hasil penelitian Arman tentang "Gagalnya Ranah Rumah Tangga menjadi Benteng Terakhir Pemetahanan Bahasa Senatni di Kampung Waena dan Kampung Yoka Kota Kayapura" (2013:56), menunjukkan di dalam ranah rumah tangga masyaraat Yoka dan wena di Kota Jayapura orangorang tua dan anak-anak tidak aktif lagi mempergunakan bahasa Sentani.

Kelima, hasil pengamatan Gunarwan yang didukung oleh Fisman, Reyhner (dalam Gunarwan, 2011:137), menunjukkan sejumlah bahasa daerah sudah berada pada taraf delapan, taraf yang rapuh dan mencemaskan. Di antara bahasabahasa daerah yang ada di Indonesia hanya menyisahkan segelintir penutur tua dan secara lingual tidak interaktif lagi antargnerasi. Banyak generasi muda berpendidikan tinggi tidak mampu lagi berbicara dan berdialog dalam bahasa daerah dengan generasi tuanya dalam hal adat dan budaya lokal.Keenam, hasil penelitian Sailan (2014:191-200) terhadap pemertahanan bahasa Muna di Kabupaten Muna Sulawesi tenggara, menunjukkan, antara lain (1) pemertahanan orang tua menguat pada orang tua di pedesaan dan sebaliknya melemah pada ranah keluarga berpendidikan, keluarga dwisuku, kalangan elit, dan lingkungan sekolah, dan (2) secara demografi tampak bahwa ... penduduk usia 0-19 tahun mulai kurang aktif berbahasa Muna, usia 20-49 tahu tidak peduli dengan penggunaan bahasa Muna, dan usia 50 tahun ke atas masih mampu berbahasa Muna secara aktif.
Ketujuh, hasil penelitian Setyaningsih (2014:27-36), menunjukan, faktor penyebab menurunnya jumlah pengguna bahasa Jawa oleh Masyarakat Jawa, antara lain (1) faktor diglosik (dua bahasa berdampingan) tetapi ada yang Ragam Tinggi (T) dan ada pula yang ragam rendah (R), dan (2) faktor pendidikan.

\section{METODE}

Penelitian ini menggunakan jenis penelitian kualitatif deskriptif-singkronis yang dikemukakan oleh Mahsun (2005:84). Dalam hal ini peneliti melakukan pengamatan terhadap fenomena pemarjinalan bahasa Suwawa pada saat ini. Data diperoleh melalui teknik pengamatan berperan serta, wawancara mendalam, dan catatan serta dibantu dengan rekaman video (bandingkan Mulyana, 2003:173, Sugiyono, 2009:145, dan Mahsun, 2005:91).

Data dan sumber data dalam penelitian ini, merujuk pada perspektif Arikunto, (2002:25), yaitu (1) manusia berupa peneliti sendiri sebagai kunci utama, unsur keluarga (orang tua dan seluruh anggota keluarga) dalam satu rumah tangga, generasi muda, pemangku adat, pendidik, tokoh agama, tokoh masyarakat, dan pemerintah, (2) situasi berupa situasi santai, duka, jual beli di pasar, dan dalam rumah, (3) kejadian atau peristiwa, berupa kejadian/peristiwa kematian, acara keluarga, pembelajaran, penyuluhan, kampanye, dan rapat, dan (4) penampilan atau perilaku berupa bahasa atau kata-kata, baik verbal maupun nonverbal. Dalam menganalisi data, peneliti menggunakan model analisis Miles dan Hubermas, yaitu analisis sebelum ke lapangan, ketika di lapangan, dan setelah dari lapangan.

\section{HASIL DAN PEMBAHASAN Faktor Penyebab Pemarjinalan Bahasa Suwawa}

Berdasarkan hasil penelitian diperoleh faktor penyebab pemarjinalan bahasa Su- 
wawa, meliputi faktor konseptual, faktor operasional, faktor sikap, dan faktor sikap bahasa. Faktor pemarjinalan dari aspek konseptual terutama berkaitan dengan (1) keterbatasan pengetahuan tentang asal-usul, kedudukan dan fungsi bahasa Suwawa(2) rumit dan uniknya bahasa Suwawa.

\section{Faktor Pemarjinalan Bahasa Suwawa dilihat dari Aspek Konseptual}

Faktor pemarjinalan dari aspek konseptual berdasarkan hasil penelitian, meliputi (1) keterbatasan pengetahuan tentang asal-usul, kedudukan dan fungsi bahasa Suwawa(2) rumit dan uniknya bahasa Suwawa. Faktor penyebab point (1) dari 54 kepala keluarga kesemuanya (100\%) menggunakan bahasa Suwawa, tetapi setelah diwawancarai tentang pengetahuan dan pemahaman mereka terhadap asal-usul, kedudukan, dan fungsi bahasa Suawa, hanya 21 (38.89\%) yang menjawab "ya", sedangkan 33 (61.11\%) menjawab "tidak". Dari 7 orang tokoh agama dan tokoh adat semuanya (100\%) menjawab "ya". Dari 28 unsur pemerintah Kecamatan dan desa yang ada di wilayah Suwawa dan Bone Pantai hanya 3 orang $(10.71 \%)$ yang mejawab "ya", sedangkan 25 (89.29\%) menjawab "tidak". Dari 11 orang pendidik, semuanya $(100 \%)$ menjawab "tidak". Dari 42 orang generasi muda semuanya (100\%) menjawab "tidak". Dengan kata lain, dari 242 informan hanya 31 orang $(12.81 \%)$ yang mengetahui asal-usul, kedudukan, dan fungsi bahasa Suwawa, sedangkan 211 $(87.19 \%)$ tidak mengetahui. Mereka dapat berbahasa Suwawa hanya karena secara turun temurun dari leluhurnya menggunakan bahasa Suwawa dalam berinteraksi sesamanya.

Penyebab (2) di samping kerumitan fonologi, morfologi, sintaksis, dan semantiknya, juga intonasi pengucapannya. Pengucapan bahasa Suwawa kedengarannya berirama atau berlagu (panjang).
Berdasarkan keterangan informan hal demikian menunjukkan bahwa masyarakat Suwawa memiliki sikap santun dan rendah hati. Bahkan salah seorang informan, mengatakan "Bukan orang Suwawa kalau tidak santun dalam bertindak tutur". Hal ini tampak pada, antara lain penggunaan pilihan kata yang santun/tawadlu, misalnya kata "ami" (kami) dalam kalimat "Wagu doizinia ami domotombilu moloia" (kalau sudah diizinkan kami akan berbicara dan berkata), karena kerendahan hati pilihan kata tersebut diperhalus dengan mengucapkan "wagu do izinia amigiyateal amigiyatotea domotombilu moloia". Kata amigiyatea/amigiyatotea merupakan perwujudan nilai-nilai budaya "tawadlu" atau merendahkan diri di hadapan pembesar, pemimpin, atau yang dituakan. Masalahnya, adalah peniruan penekanan intonasi sering dilakukan secara berlebihan oleh orang yang bukan etnis Suwawa. Misalnya, ati a:ma ... (kasiha...n ...), (yi) nongonu yi:o:? (mengapa engka ...u ...). Peniruan pengucapan yang berlebihan seperti ini di samping membuat orang Suwawa tersinggung ada pula yang merasa malu dan berkecil hati sehingga tidak mau lagi berbahasa Suwawa (terutama generasi muda yang berusia 20 tahun ke bawah). Di samping itu, dari 42 orang pemuda semuanya (100\%) tidak dapat membedakan pengucapan dan penggunaan fonem dan huruf ' $n d$ ' dan ' $n t$ '. Misalnya, 'nta mongonu yio?" (sedang apa engkau/Anda)? diucapkan "nda mongonu yio"?, 'binte' (jagung) diucapkan 'binde', 'intea (tidak)' diucapkan 'indea'. Hal ini berbeda dengan kata dindi (dinding), pengucapannya tetap dinding dan bukan dinti.

Ketidaktahuan dan ketidakmampuan memahami kedudukan dan fungsi bahasa Suwawa ini identik dengan hasil penelitian Wahab (2011:155), yakni "Secara kuantitatif, generasi muda yang berasal dari keluarga pemilik asli bahasa, sastra, dan aksara daerah tidak mampu melihat pentingnya fungsi dan kedudukan ba- 
hasa, sastra, dan aksara daerah. Generasi muda usia 20 tahun ke bawah kurang atau tidak memedulikan penggunaan aksara daerah secara reseptif maupun secara produktif.

Selajutnya, berdasarkan pengamatan dan wawancara dengan para guru serta kepala sekolah di beberapa TK dan SD yang ada di Suwawa dan Bone Pantai dari 11 orang, semuanya (100) mengatakan "Mau membelajarkan bahasa Suwawa kepada anak didiknya". Akan tetapi (1) guru itu sendiri tidak bisa berbahasa Suwawa, (2) bahasa Suwawa belum masuk dalam kurikulum muatan lokal, dan (3) buku ajar/rujukan belum tersedia. Hal ini identik dengan hasil penelitian Supardi (2015:11) tentang "Problematika Pembelajaran Bahasa Ibu di Papua". Hasil penelitiannya menunjukkan, antara lain (1) sebahagian besar bahasa itu hanya didukung oleh jumlah penutur yang kurang untuk dapat diselenggarakan PMB-BBI, (2) sebagian besar belum diteliti sehingga sistem fonemnya belum diketahui, (3) belum ada secara lengkap pemetaan bahasa, vitalutas bahasa, dan pemetaan sekolah, dan rancangan pembelajaran dan bahan ajar masih sangat terbatas pada bahasa ibu.

Faktor ketidaktahuan masyarakat Suwawa pada bahasa Suwawa, tampaknya berdampak padapertama, penamaan nama-nama desa pemekaran yang ada di wilayah Suwawa dan Bone Pantai. Hasilpenelitian menunjukkan, setelah dimekarkan sejak 25 Februari 2003 sampai sekarang berjumlah 152 desa dan 4 kelurahan, hanya 34 (21.79\%) desa yang menggunakan nama dalam bahasa Suwawa, $84(55.26 \%)$ menggunakan nama dalam bahasa Gorontalo, dan 34 (21.79\%) menggunakan nama dalam bahasa Indonesia.

Kedua, semakin merosotnya penggunaan bahasa Suwawa dalam berbagai kalangan. Di lingkungan keluarga/rumah tanggarata-rata berjumlah 4-5 orang. Akan tetapi, yang bisa berbahasa Suwawa ting- gal 1 - 2 orang (20-40\%), yaitu bapak atau ibu atau bapak dan ibu. Namun demikian, di beberapa rumah tangga/keluarga pada desa-desa tertentu masih ada sekisar 60$80 \%$ yang berbahasa Suwawa dalam berinteraksi sesama anggota keluaraganya. Di lingkungan sekolah tinggal 20\%, di lingkungan masyarakat masih 79, 21\%, di lingkungan pemerintah daerah tinggal $30 \%$, dan di lingkungan tokoh adat dan tokoh agama masih $85 \%$.

Tingkat pemarjinalan bahasa Suwawa demikian, jika dikaji dari postulat Fishman (dalam Yadnya, 2011:171), masih dapat dikategorikan ke taraf 7-1 dan belum masuk pada taraf 8 . Taraf 8 ditandai dengan kebahasaan yang hanya sedikit sekali orang tua yang mampu berbahasa ibu.Taraf 7 adalah situasi kebahasaan yang ... memiliki masih cukup banyak penutur, tetapi dari generasi tua (berusia lanjut) .... Taraf 6, masih terdapat penggunaan bahasa ibu antargenerasi di rumah. Taraf 5, bahasa Suwawa masih hidup dan digunakan dalam kelompok minoritas dan bahkan di sekolah. Taraf 4, bahasa minoritas diharuskan pada pendidikan sekolah dasar. Taraf 3, bahasa daerah (Suwawa) digunakan di tempat kerja oleh para pekerja dalam lingkungan kerja khusus. Taraf 2. bahasa daerah (Suwawa) digunakan dalam pemerintah setempat (lokal) dan media massa dari komunitas minoritas. Taraf 1, bahasa daerah tersebut digunakan dalam tataran pemerintahan yang lebih tinggi dan pendidikan tinggi.

Faktor Penyebab Pemarjinalan Bahasa Suwawa dilihat dari Aspek Operasional Faktor Penyebab Pemarjinalan Bahasa Suwawa dilihat dari Aspek Lapangan

Masalah lapangan (lokasi) pembinaan dan pengembangan bahasa Suwawa yang ada di Suwawa dan Bone Pantai memang masih banyak terpencil dan sulit dijangkau dengan kenderaan roda dua maupun roda empat. Lokasi terpencil di daerah Suwawa, antara lain Tulabolo Barat, 
Tulabolo Timur, Pinogu, Pinogu Permai, Poduoma, dan Bangio.

\section{Faktor Penyebab Pemarjinalan Bahasa} Suwawa dilihat dari Aspek Ketenagaan

Masalah ketenagaan yang membinan dan mengembangkan bahasa di Provinsi Gorontalo masih sangat terbatas. Di Provinsi Gorontalo sudah ada Kantor Bahasa. Akan tetapi, di lembaga tersebut tenaganya di samping sangat terbatas juga rata-rata berasal dari luar daerah. Meskipun terdapat putra dan putri Gorontalo, namun mereka tidak bisa berbahasa Suwawa. Mereka justru lebih fasih berbahasa Inggeris atau berbahasa Indonesia daripada berbahasa Suwawa, apalagi bahasa Gorontalo, Atinggola dan bahasa Bulango. Demikian juga, tenaga di PT masih sangat terbatas.

\section{Faktor Penyebab Pemarjinalan Bahasa} Suwawa dilihat dari Aspek Kelembagaan

Masalah kelembagaan yang merupakan penyebab pemarjinalan bahasa Suwawa, berdasarkan pengamatan sebenarnya sudah memadai. Lembaga yang dimaksud, yaitu (1) lembaga pendidikan dan kebudayaan, (2) Lembaga Pemerintah daerah (Gubernur) sebagai penentu kebijakan dan pemegang hak otonomi daerah dalam memelihara dan melestarikan bahasa dan budaya daerah, (3) Pemerintah Kabupaten/Kota, Kecamatan, Desa/Kelurahan, (4)/Kantor Bahasa Provinsi, Prodi Pendidikan Bahasa dan Sastra Indonesia yang ada di FSB UNG, (5) Lembagalembaga adat, Pusat Bahasa yang ada di UNG, (6) Lembaga atau sanggar budaya yang ada di Provinsi dan Kabupaten/ Kota Gorontalo, dan (7) Dinas Pariwisata. Akan tetapi, lembaga-lembaga ini belum terintegrasi dalam melaksanakan pembinaan dan pengembangan bahasa-bahasa daerah yang ada di Gorontalo termasuk bahasa Suwawa.
Faktor Penyebab Pemarjinalan Bahasa Suwawa dilihat dari Aspek Kebijakan

Berdasarkan pengamatan dan wawancara dengan 3 orang Camat (Suwawa, Suwawa Tengah, dan Suwawa Selatan), serta 2 orang Kades, yaitu Kades Bondawuna dan Kades Lompotoo), diperoleh informasi, mereka telah mengambil kebijakan, antara lain (1) mewajibkan seluruh aparat kecamatan dan desa menggunakan bahasa Suwawa setiap hari Jumat dalam berkomunikasi antarsesama di lingkungan kerja (di kantor), (2) setiap rapat dengan masyarakat, baik Camat maupun Kades selalu menggunakan bahasa Suwawa dalam berinteraksi, (3) menginstruksikan/ mewajibkan pemangku adat menggunakan bahasa Suwawa ketika menuturkan tuja'I pada prosesi adat (perkawinan, penyambutan tamu, penobatan, dan pemakaman) di wilayah Suwawa, (4) menginstruksikan/mewajibkan tokoh agama menggunakan bahasa Suwawa ketika melaksanakan memberikan ceramah dan berhotbah di wilayah Suwawa, (5) menginstruksikan/mewajibkan penggunaan bahasa Suwawa pada tulisan spanduk dan gapura berupa slogan atau pengumumam di wilayah Suwawa.

Beberapa kebijakan dimaksud tampak dalam gambar berikut.

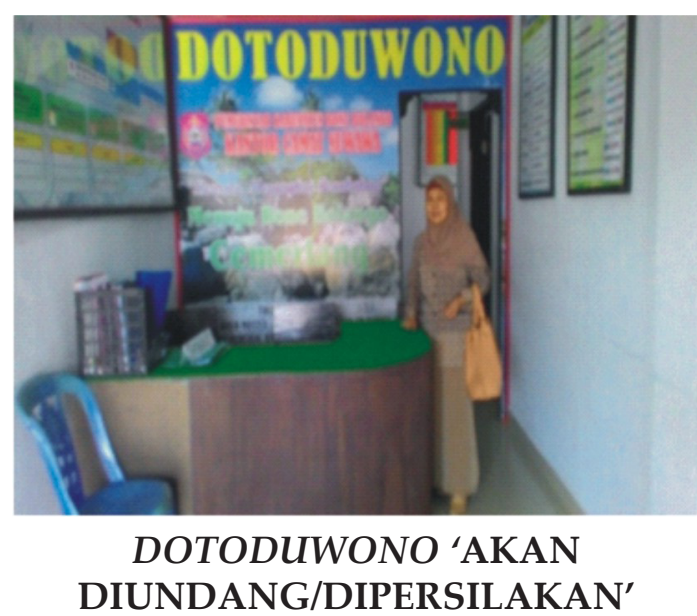




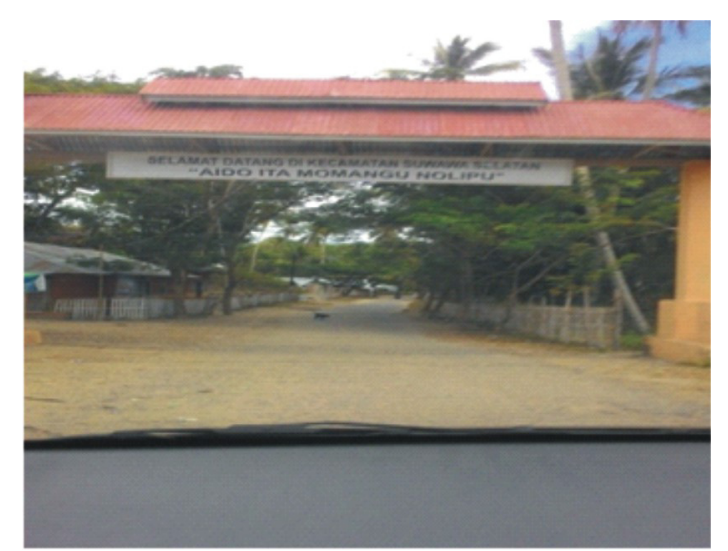

AIDO ITA MOMANGU NO LIPU 'MARI KITA MEMBANGUN NEGERI'

\section{Faktor Penyebab Pemarjinalan Bahasa Suwawa dilihat dari Aspek Sarana dan Prasarana}

Berdasarkan hasil pengamatan dan wawancara dengan para informan (pendidik) di beberapa sekolah di wilayah Suwawa dan Bone Panatai, dari 11 informan semuanya $(100 \%)$ mengatakan penyebab pemarjinalan bahasa Suwawa, yakni (1) kurikulum, (2) buku ajar, (3) kamus, (4) laboratorium/sanggar bahasa, (5) dana, dan (6) sarana dan prasarana lainnya.

Masalah sarana dan prasarana juga menjadi penghambat dalam pembinaan dan pengembangan bahasa dan sastra sehingga pemarjinalan pun terjadi. Sarana dan prasarana dimaksud masih ada lembaga-lembaga sebagaimana yang dipaparkan sebelumnya, tetapi sarana untuk pengembangan bahasa dan sastra (khusunya bahasa dan sastra daerah) belum memadai. Sebagai contoh, jurusan bahasa dan sastra Indonesia membutuhkan lab bahasa. Akan tetapi sampai saat ini lab itu hanya namanya ada tetapi sarana dan prasarana yang dibutuhkan sampai saat ini belum tersedia. Di samping itu, dana penunjang untuk itu juga tidak tersedia. Dengan demikian, beberapa kegiatan praktikum terpaksa harus dibiayai sendiri oleh mahasiswa dan dosen yang bersangkutan.
Faktor Penyebab Pemarjinalan Bahasa Suwawa dilihat dari Aspek Sikap

Berdasarkan hasil pengamatan dan wawancara dengan para informan/ generasi muda yang berusia 20 tahun ke bawah, pada umumnya masih memiliki sikap kognitif, afektif, dan konatif. Lambert (dalam Chaer dan Agustina (2004:150), mengemukakan sikap terdiri atas sikap kognitif, sikap afektif, dan sikap konatif. Sikap kognitif berhubungan dengan pengetahuan mengenai alam sekitar dan gagasan yang biasanya merupakan kategori yang dipergunakan dalam proses berpikir. Sikap afektif menyangkut masalah penilaian baik, suka atau tidak suka terhdap sesuatu keadaan, Sikap konatif mnyangkut perilaku atau perbuatan sebagai putusan akhir, kesiapan rekatif terhdap suatu keadaan.

Berdasarkan hasil penelitian, menunjukkan sikap kognitif masyarakat Suwawa (Genarasi Muda) dari 42 informan, 37 $(88.09 \%)$ mengatakan kurang tertarik atau tidak termotivasi mempelajari dan menguasai bahasa Suwawa, sedangkan sisanya $5(11.90 \%)$ mengatakan sangat tertarik. Hal ini disebabkan mereka tidak mengenal dan tidak mendapatkan pengetahuan serta pemahaman, baik dari orang tua, keluarga, sekolah, dan masyarakat sekitarnya mengenai asal-usul, kedudukan, dan fungsi bahasa Suwawa.

Sikap afektif masyarakat Suwawa (generasi muda) terhadap bahasa Suwawa, menunjukkan dari42 orang generasi muda 27 (64.29\%) mengatakan masih senang dan ingin berbahasa Suwawa, tetapi mereka tidak paham dan meskipun paham malu menggunakannya. Sikap konatif masyarakat Suwawa (Generasi Muda) terhadap bahasa Suwawa dari 42 generasi muda 25 (59.52\%) mengatakan siap untuk belajar bahasa Suwawa termasuk belajar bahasa Suwawa melalui penuturan tujaqi pada prosesi adat perkawinan khususnya. Di samping itu, dari 11 orang guru dan 1 orang kepala 
sekolah semuanya (100\%), mengatakan siap mengajarkannya di sekolah jika ada kurikulum dan buku ajar.

Sehubungan dengan ketiga sikap tersebut, hasil survey Unesco yang dikutip Lauder (dalam Mbete, 2011:133) dari 90 bahasa minoritas yang disurvei di sejumlah Negara, hanya 36\% terwaris secara mulus, $64 \%$ tidak terwaris secara baik, 32\% berfungsi, $68 \%$ bahasa minoritas itu tidak berfungsi lagi. Selanjutnya, hasil penelitian Bagus, dkk, Gunarwan, dan Mbete (dalam Gunarwan, 2011:137) menunjukkan ranah keluarga sebagai benteng terakhir, khususnya di kota dan di desa-desa yang sudah tergolong maju, bahasa daerah tidak mendapat posisi dan fungsi penting lagi karena sudah diambil alih oleh bahasa Indonesia.

\section{Faktor Penyebab Pemarjinalan Bahasa Suwawa dilihat dari Aspek Sikap Bahasa}

Berdasarkan pengamatan berperan serta, masyarakat Suwawa pada dasarnya masih memiliki sikap bahasa sebagaimana yang dikemukakan oleh Garvin dan Mathiot (dalam Chaer dan Agustina. 2004:152), yaitu kesetiaan bahasa (language loyality), kebanggaan bahasa (language pride), dan kesadaran noram bahasa (awareness of the norm).Kesetiaan bahasa (language loyality) yang mendorong masyarakat suatu bahasa mempertahankan bahasanya, dan apabila perlu mencegah adanya pengaruh bahasa lain, Kebanggaan bahasa (language pride) yang mendorong orang mengembangkan bahasanya dan menggunakannya sebagai lambang identitas dan kesatuan masyarakat. Kesadaran akan norma bahasa (awareness of the norm) yang mendorong orang menggunakan bahasanya dengan cermat dan santun.

Ketiga sikap bahasa tersebut, berdasarkan penelitian masih ditemukan pada masyarakat Suwawa meskipun tidak lagi sesuai harapan. Dari 242 informan 52 $(21.49 \%)$ sudah kehilangan rasa bangga terhadap bahasa Suwawa. Hal ini dikarenakan ketidaktahuan, keterlibatan dalam politik, berkedudukan sebagai pejabat, gengsi, dan malu. Sikap kesetiaan bahasa masyarakat Suwawa juga masih ditemukan, tetapi mencegah pengaruh bahasa lainnya sulit dibendung. Sikap kesadaran akan norma bahasa masih dimiliki oleh masyarakat Suwawa secara dominan. Gambaran sikap kesadaran akan norma bahasa (awareness of the norm) masyarakat Suwawa identik dengan apa yang dikemukakan oleh Pateda (2005:53) berikiut. Pateda membedakan pengungkapan bahasa atau sikap berbahasa di desa dan di kota. Pengungkapan bahasa/ sikap berbahasa di desa masih terdengar tekanan nada dan pilihan kata yang penuh kemesraan dan gotong royong serta kebersamaan, tetapi di kota bahasa itu sudah dipengaruhi oleh dominasi rasio telah menjadikan kebudayaan itu kering dan kasar. Indvidualisme telah membuat perhubungan secara manusiawi kehilangan kemesraan. Sebagai contoh, jika Anda datang ke suatu kota besar dan menanyakan alamat seseorang, pasti jawabannya tidak tahu lalu pergi meninggalkan Anda tanpa tegur sapa dan dengan ekspresi penuh kecurigaan dan ketakutan. Sebaliknya, jika Anda pergi ke suatu desa yang masih ramah lingkungan dan jika Anda bertanya tentang alamat seseorang, pasti Anda akan ditegur sapa dengan penuh hormat dan santun. Misalnya, Bapak/Ibu/Anda siapa dan dari mana? Kenal apa dengan dia (yang dicari)? Kalau pun orang tersebut tidak mengenal orang yang Anda cari, setidaknya orang tersebut (tempat Anda bertanya) akan mengajak Anda bersamasama menanyakan ke tetangganya dan berusaha menemani Anda sampai bertemu dengan orang yang Anda cari. Menyenangkan, bukan? 
Strategi Pencegahan Pemarjinalan Bahasa Suwawa

Strategi Pencegahan Pemarjinalan Bahasa Suwawa dari Aspek Pendidikan

Strategi pencegahan pemarjinalan bahasa Suwawa dapat dilakukan melalui pendidikan, baik di lingkungan keluarga, lingkungan sekolah, maupun lingkungan masyarakat. Strategi yang telah dan akan dilakukan di ligkungan keluarga, berdasarkan pengamatan dan wawancara, yaitu (1) Ibu atau ayah (Ayah dan Ibu) selalu menggunakan bahasa Suwawa dalam berkomunikasi dengan seluruh anggota keluarga termasuk dengan anak-anak di rumah, (2) memperkenalkan tentang asal-usul, kedudukan, dan fungsi bahasa Suwawa kepada seluruh anggota keluarga terutama kepada anak-anak berusia 20 tahun ke bawah, (3) menghimpun warga masyarakat etnis Suwawa dalam wadah arisan keluarga yang dikenal dengan "Bu:gota wa:nama inogaluma no poganaa" (ikatan dan anyaman/persatuan dan kesatuan yang disepakati bersama keluarga). Hal ini dibentuk pada 31 Agustus 2015. Tujuannya yaitu (1) menghimpun dan mempererat kembali hubungan silaturrahim antarkeluarga, (2) membangun kembali nilai-nilai budaya berupa solidaritas antarsesama keluarga, dan (3) mengangkat serta melestarikan kembali penggunaan bahasa Suwawa terutama di lingkungan keluarga.

Strategi pencegahan pemarjinalan bahasa Suwawa yang akan dilakukan berdasarkan permintaan pendidik di lingkungan sekolah ketika diwawancarai, yakni semua pihak yang terkait bersamasama (1) merumuskan kurikulum muatan lokal tentang bahasa Suwawa, (2) menyusun dan menerbitkan buku/materi ajar, (3) menyusun dan menerbitkan kamus bahasa Suwawa, (4) menyusun dan menerbitkan kamus istilah bahasa Suwawa, dan (5) mengadakan laboratorium/sanggar bahasa, serta (6) penyediaan alokasi dana yang memadai. Hal ini sebagaimana telah dikumandangkan dan diputuskan dalam Kongres Bahasa Indonesia VII tahun 1998 (Badan Pengembangan dan Pembinaan Bahasa Kemendikbud, 2011a:86-87), yaitu (1) penerbitan buku, surat kabar, dan majalah dalam bahasa daerah perlu digiatkan dan didorong, dan (2) pengembangan bahan ajar bahasa daerah perlu dilakukan dengan memanfaatkan sumber-sumber rujukan yang telah diterbitkan oleh Pusat Pembiaan dan Pengembangan Bahasa dan/atau lembaga lain yang bersangkutan. Hal senada juga dikemukakan oleh Bawa (2011:337), yakni untuk memantapkan peran bahasa daerah dapat dilkukan dengan memantapkan mutu pemakaian bahasa daerah yang antara lain melalui pengajaran dan pemasyarakatan. Agar mutu pemakaiannya meningkat, selain melalui pengembangan kurikulum, juga disertai dengan pengembangan bahan ajar, memanfaatkan metode yang tepat, pengembangan tenaga pengajar, dan mengembangkan sarana pendidikan bahasa.

Sehubungan dengan strategi pencegahan pemarjinalan bahasa, Mbeto (dalam Sutama, 2014:42), mengemukakan lima strategi pemertahanan bahasa-bahasa Nusantara, yakni (1) peningkatan disiplin menggunakana bahasa daerah, nasional, dan internasional sesuai dengan ranah pemakaian masing-masing, (2) pembenahan pembelajaran bahasa daerah melalui pengembangan kurikulum, bahan ajar, model pembelajaran, dan peningkatan mutu guru, (3) kerja sama kelembagaan dan pemberayaan lembaga-lembaga tradisional, (4) penerjemahan penulisan dan teknologisasi khasanah budaya nusantara, dan (5) reorientasi kebahasaan dan kebudayaan nasional. Di samping itu, demi upaya penguatan jati diri bangsa ini, Setyaningsih (2015:27), mengemukakan kerja sama yang baik antara masyarakat dan lembaga pendidikan menjadi hal yang perlu dijalin dengan baik. Dalam keluarga peran orang tua dalam penerapan bahasa 
Jawa menjadi modal utama. Demikian juga di lingkungan sekolah, peran guru juga sangat penting untuk mengajarkan bahasa dan Budaya Jawa dengan metode yag kreatif dan menarik bgi siswa.

\section{Strategi Pencegahan Pemarjinalan Ba- hasa Suwawa dari Aspek Penelitian}

Berdasarkan pengamatan dan wawancara, dengan informan berasal dari akademisi dan pihak Kantor Bahasa Provinsi Gorontalo, strategi yang telah dan akan dilakukan untuk mencegah pemarjinalan bahasa Suwawa, yakni (1)pihak akademisi UNG bekerja sama dengan Pengelola Kantor Bahasa Provinsi Gorontalo telah melakukan penelitian terhadap kebahasaan dan kesastraan dalam bahasa Suwawa, (2) memetakan hasil penelitian tersebut dan menetukan hal/aspek yang lebih urgenyang dibutuhkan oleh siswa dan guru, (3) dalam melakukan penelitian melibatkan masyarakat yang ada di daerah sasaran, (4) setiap bulan Oktober dijadikan sebagai moment pelestarian bahasa daerah yang ada di Gorontalo, berupa seminar, pelatihan, workshop, lomba, baik cipta dan baca puisi, menulis dan menyampaikan pidato/ceramah, debat, memimpin rapat, menyusun dan memandu acara, dan bercerita (cerita rakyat) dengan menggunakan bahasa Suwawa.

Strategi Pencegahan Pemarjinalan Bahasa Suwawa dari Aspek Pengabdian kepada Masyarakat

Strategi yang telah dan akan dilakukan, yakni (1) sosialisasi dan pelatihan kepada guru tentang program (kurikulum) dan materi ajar bahasa Suwawa, (2) menggunakan sumber (informan) yang (i) paham dan menguasai sejarah tentang asal usul bahasa Suwawa, (ii) penutur asli yang berumur di atas 50 tahun, dan (iii) penduduk asli Suwawa yang masih jarang melakukan kontak bahasa lainnya, (3) pihak pengelola Kantor Pengembangan dan Pmbinaan Pusat melalui Kantor Bahasa Provinsi Gorontalo telah melatih salah satu generasi muda yang berasal daerah terpencil, yaitu di Paguyaman Pantai pada tahun 2012, (4) semua unsur terkait bersatu padu melakukan pembinaan dan pengembangan bahasa daerah (Suwawa) dalam berbagai kegiatan, antara lain kampanye/penyuluhan Pemertahanan Bahasa Suwawa di tingkat kecamatan dan desa yang ada di daerah Suwawa dan sekitarnya. Hal ini telah dilakukan oleh Kantor Bahasa Provinsi Gorontalo dengan melibatkan PT pada11 Agustus 2015 dan Bina Desa Bahasa Suwawa, 14 Desember 2015 di Suwawa Timur, (5) melibatkan penutur asli bahasa Suwawa dalam kegiatan pembinaan dan pengembangan bahasa Suwawa, baik yang dilaksanakanoleh Kantor Bahasa, Kemendikbud, Dinas Pariwisata, maupun oleh PT khususnya Prodi Pend. Bahasa dan Sastra Indonesia, (6) menambah tenaga penyuluh/Pembina bahasa di Kantor Bahasa Provinsi dengan lebih mengutamakan orang yang memiliki motivasi dan dedikasi tinggi untuk membina dan mengembangkan bahasa daerah yang ada di Gorontalo termasuk bahasa Suwawa. Dalam hal ini Pateda (2005:143), mengatakan "Strategi pemertahanan bahasa daerah dapat dilaksanakan dengan pendekatan secara sengaja dan ilmiah dengan melibatkan (1) birokrat/pemerintah, (2) pakar bahasa, (3) guru, (4) tokohtokoh informal, misalnya tokoh pemuda, tokoh masyarakat, tokoh agama, dan tokoh adat.

Selanjutnya, sesuai Keputusan Kongres Bahasa Indonesia VII tahun 1998 (Badan Pengembangan dan Pembinaan Bahasa Kemendikbud, 2011a:86-87), dijelaskan "Pemerintah perlu memberikan penghargaan kepada tokoh-tokoh yang telah berjasa besar dalam pembinaan dan pengembangan bahasa daerah". Hal ini telah dilakukan oleh Kantor Bahasa Provinsi Gorontalo, yaitu memberikan penghargaan kepada tokoh-tokoh sa- 
trawan, budayawan, dan bahasawan asal Gorontalo, masing-masing (1) Bapak Risno Ahaya (Pegambus dan pelantun Pa:tungi) tahun 2013, (2) Anugerah H.B. Jassin" (sastrawan Indonesia) tahun 2015, (3) Kadis Kemendikbud Kota Gorontalo (Pemerhati Bahasa Indonesia) tahun 2015, (4) Alm. Prof. Dr. Mansoer Pateda (Pelestari Bahasa dan budaya Gorontalo) tahun 2015, dan (5) Prof. Dr. Nani Tuloli (Sastrawan Gorontalo) tahun 2015.

\section{SIMPULAN}

Berdasarkan paparan sebelumnya, dapatlah disimpulkan, (1) termarjinal tidaknya bahasa Suwawa sangat ditentukan oleh (i) peran serta keluarga (orang tua) dalam mengintensifkan penggunaan bahasa Suwawa (ii) keseriusan Pemerintah Daerah dan Kemnedikas melalui Kantor Bahasa dalam hal memfasilitasi pembinaan dan pengembangan bahasa daerah (Suwawa), (2) faktor penyebab pemarjinaan bahasa Suwawa lebih banyak berasal dari generasi muda dan guru, baik dari faktor konseptual, opersional, sikap, maupun sikap bahasa.

Untuk mencegah penyebab pemarjinalan bahasa Suwawa tersebut dapat dilakukan dengan berbagai strategi. Strategi yang dimaksud, baik melalui pendidikan di lingkungan keluarga, sekolah, maupun masyarakat, penelitian, dan pengabdian kepada masyarakat dengan melibatkan seluruh unsur yang terkait.

\section{UCAPAN TERIMA KASIH}

Artikel ini disusun berdasarkan hasil penelitian yang dilaksanakan pada tahun 2015 dengan dukungan anggaran PNBP UNG. Untuk itu, perlu disampaikan terima kasih kepada Kaprodi Pendidikan Bahasa dan sastra Indonesia, Dekan Fakultas Sastra dan Budaya UNG, Ketua Lemlit UNG, dan Rektor UNG, yang telah menyetujui dan merekomendasikan peneliti untuk melaksanakan penelitian. Di samping itu pula, seluruh staf tenaga kepen- didikan telah memproses, mengetik, dan menerbitkan surat tugas/rekomendasi penelitian. Ucapan terima kasih disampaikan pula kepada seluruh informan yang telah sukarela membantu memberikan informasi dan keterangan serta data yang dibutuhkan oleh peneliti.

\section{DAFTAR PUSTAKA}

Arikunto, Suharsimi. 2010. Prosedur Penelitian: Suatu Pendekatan Praktis. Jakarta: PT Rineka Cipta

Arman. 2013. Gagalnya Ranah Rumah tangga Menjadi Benteng Terakhir Pemertahanan Bahasa sentani di Kampung Waena dan kampung Yoka Kota Jayapura. Jurnal Telaga Bahasa, Vol. 1 (01): 56-71. Gorontalo: Kantor Bahasa Provinsi Gorontalo Badan Pengembangan dan Pembinaan Bahasa Kemetrian Pendidikan dan Kebudayaan

Badan Pengembangan dan Peminaan Bahasa Kemendikbud. 2011a. Kumpulan Putusan Kongres Bahasa Indonesia 1 - IX Tahun 1983-2008. Jakarta: Badan Pengembangan dan Pembinaan Bahasa Kemendikbud

Badan Pengembangan dan Pembinaan Bahasa Kemetrian Pendidikan dan Kebudayaan. 2011b. Politik Bahasa. Jakarta: Badan Pengembangan dan Pembinaan Bahasa Kemetrian Pendidikan dan Kebudayaan

Badan Pengembangan dan Pembinaan Bahasa Kemendikbud. 2011c. Undangundang RI No. 24 Tahun 2009 tentang Bendera, Bahasa, dan Lambang Negara serta Lagu Kebangsaan. Jakarta: Badan Pengembangan dan Pembinaan Bahasa Kemendikbud

Bawa, I Wayan. 2011. Perkukuh Budaya Bangsa dengan Memantapkan Peran Bahasa Daerah. Dalam Maryani, Yeyen dan Sitanggang, S.R.H (Eds.), Pemberdayaan Bahasa Indonesia Memperkukuh Budaya Bangsa dalam Era Globalisasi: Risalah Kongres Bahasa Indonesia VIII (hlm 333-342). Jakarta: 
Badan Pengembangan dan Pembinaan Bahasa Kemendikbud.

Chaer, Abdul dan Agustina Leonie. 2004. Sosiolinguistik: Perkenalan Awal Edisi Revisi. Jakarta: Rineka Cipta

Daulima, Farha. 2006. Terbentuknya Kerajaan Limboto Gorontalo: Bahan Pembelajaran Muatan Lokal. Gorontalo: Galeri Budaya Daerah LSM “Mbui Bungale"

Gunarwan, Asim. 2011. Pembalikan Pergeseran Bahasa Daerah untuk Memperkukuh Budaya. Dalam Maryani, Yeyen dan Sitanggang, S.R.H (Eds.), Pemberdayaan Bahasa Indonesia Memperkukuh Budaya Bangsa dalam Era Globalisasi:Risalah Kongres Bahasa Indonesia VIII (hlm 115-132). Jakarta:Badan Pengembangan dan Pembinaan Bahasa Kemendikbud.

Mahsun. 2005. Metode Penelitian Bahasa: Tahapan, Strategi, Metode, dan Teknik. Jakarta: PT RajaGrafindo Persada

Mbete, Aron Meko. 2011. Pemekaran Fungsi Bahasa Daerah Demi Ketahanan Budaya Bangsa: Dalam Maryani Yeyen dan Sitanggang, S.R.H (Eds.), Pemberdayaan Bahasa Indonesia Memperkukuh Budaya Bangsa dalam Era Globalisasi:Risalah Kongres Bahasa Indonesia VIII (hlm 133-148). Jakarta: Badan Pengembangan dan Pembinaan Bahasa Kemendikbud.

Mulyana, Deddy. 2003. Metodologi Penelitian Kualitatif: Paradigma Baru Ilmu Komunikasi dan Ilmu Sosial lainnya. Bandung: PT Remaja Rosdakarya

Peteda, Mansoer. 2005. Sosiolinguistik. Gorontalo: Viladan

Redaksi Sinar Grafika. 2006. Undangundang Sisdiknas (Sistem Pendidikan Nasional) 2003 (UU RI No. 20 Th. 2003). Jakarta: Sinar Grafika

Sailan, Zailili. 2014. Pemertahanan Bahasa Muna di Kabupaten Muna Sulawesi Tenggara. Litera: Jurnal Penelitian Bahasa, Sastra, dan Pengajarannya FBS UNY, (Online), Http://journal.uny.ac.id,
Vol. 13. No.1:191-200, diakes 2 Maret 2017.

Setyaningsih, Nur Ramadhoni. 2015. Pengenalan Bahasa Jawa pada Anak sebagai Bentuk Pemberdayaan Bahasa Lokal dan Upaya Pengetahuan Jati Diri Bangsa. Jurnal Tutur: Cakrawala Kajian Bahasa-bahasa Nusantara, Vol. 01 (01): 27-36. Bali: Asosiasi Peneliti Bahasa-bahasa Lokal (APBL)

Sugiyono. 2009. Metode Penelitian Kuantitaif Kualitatif dan $R \mathcal{E} D$. Bandung: Alfabeta

Supardi. 2015. Problematika Pembelajaran Bahasa Ibu di Papua. Jurnal Tutur: Cakrawala Kajian Bahasa-bahasa Nusantara, Vol. 01 (01): 11-18. Bali: Asosiasi Peneliti Bahasa-bahasa Lokal (APBL).

Sutama, I Made. 2015. Hari Berbahasa daerah di Sekolah dalam Perspektif Pemerolehan dan Pemertahanan Bahasa. Jurnal Tutur: Cakrawala Kajian Bahasa-bahasa Nusantara, Vol. 01 (01): 37-45. Bali: Asosiasi Peneliti Bahasabahasa Lokal (APBL)

Tim Fokus Media. 2004. UUD 1945 dan Amandemennya. Bandung: Fokus Media

Undang-Undang Sisdiknas (Sistem Pendidikan Nasional) 2003: UU RI No. 20 Th. 2003). 2006. Jakarta: Sinar Grafika

Wahab, Abdul. 2011. Masa Depan Bahasa, Sastra, dan Aksara Daerah. Pemberdayaan Bahasa Indonesia Memperkukuh Budaya Bangsa dalam Era Globalisasi:Risalah Kongres Bahasa Indonesia VIII. Dalam Maryani Yeyen dan Sirear, S.R.H (Ed.). 2011. hlm 155-185. Jakarta: Badan Pengembangan dan Pembinaan Bahasa Kemendikbud.

Wahyudi, Ibnu (Ed.). 2004. Menyoal Sastra Marginal. Jakarta: Wedatama Widya Sastra.

Wantogia dan Wantogia. 1984. Sejarah Gorontalo: Asal Usul dan Terbentuknya Kerajaan Suwawa, Limboto, dan Goron- 
talo. Gorontalo: Toko Buku “Tambibulawa"

Wiryamartana, I Kuntara. 2004. "Memperimbangkan Sastra Marginal dari Kajian Penelitian". Menyoal Sastra Marginal. Dalam Wahyudi Ibnu. 2004. hlm 66. Jakarta: Wedatama Widya Sastra

Yadnya, Ida Bagus Putra. 2011. Revitalisasi Bahasa Daerah (Bali) di Tengah
Persaingan Bahasa Nasional, Daerah, dan Asing untuk Memperkukuh Ketahanan Budaya. Pemberdayaan Bahasa Indonesia Memperkukuh Budaya Bangsa dalam Era Globalisasi:Risalah Kongres Bahasa Indonesia VIII. Dalam Maryani Yeyen dan Sirear, S.R.H (Ed.). 2011. hlm 171-185. Jakarta: Badan Pengembangan dan Pembinaan Bahasa Kemendikbud. 